\title{
Managing Risk in Livestock Farming: The Role of Insurance Companies
}

\author{
Sanam Jokhio ${ }^{1}$, Muhammad Moinuddin Qazi Abro $^{2} \&$ Lamya Alaali $^{3}$ \\ ${ }^{1}$ Mehran University Institute of Science, Technology and Development, Mehran University of Engineering and \\ Technology, Jamshoro Sindh, Pakistan \\ 2 Department of Management, College of Business Administration, King Saud University, Riyadh, Kingdom of \\ Saudi Arabia \\ ${ }^{3}$ Department of Finance Companies Control, Saudi Arabian Monetary Agency (SAMA), Riyadh, Kingdom of Saudi \\ Arabia \\ Correspondence: Dr. Muhammad Moinuddin Qazi Abro, Assistant Professor, Department of Management, College \\ of Business Administration, King Saud University, Riyadh, Kingdom of Saudi Arabia.
}

Received: December 17, 2015

Accepted: February 14, 2016

Online Published: March 8, 2016

doi:10.5430/ijfr.v7n2p64

URL: http://dx.doi.org/10.5430/ijfr.v7n2p64

\begin{abstract}
This research analyses the risk associated with livestock farming in relation to the utilization of insurance policies and as a risk management mechanism. Ninety percent of the farmers in this study were unaware of the existence of insurance plans; the need for risk protection among vulnerable, low-income and poor farmers is crucial, especially for those who depend on livestock for their livelihood. Data was collected from insurance companies regarding their different plans for protecting farmers and commercial livestock farmers. Not only livestock farmers face risks, but insurance companies as well. Educating farmers about how to manage the risks associated with livestock business is absolutely necessary. In addition, farmers need social protection and interventions from public, private, or charitable organizations.
\end{abstract}

Keywords: risk management, insurance companies, farmers, livestock

\section{Introduction}

Livestock is the largest sub-sector of the agriculture business; it plays a pivotal role in Pakistan's economy, mainly in the rural socio-economic system. The majority of farmers in Pakistan are landless small livestock holders. In emergencies, such as drought and other natural calamities, the livestock rescue populations living in rural areas. The risk environment for farmers is constantly changing; e.g., production costs are increasing while financial compensation from the government is non-existent. The main objectives of this paper are first, to identify the insurance companies offering insurance plans for livestock farmers, and second, to describe the widely-held beliefs of farmers/farm owners regarding insurance plans and risk management.

\section{Literature Review}

Risk in farming is an age-old phenomenon. Due to unpredictable weather and other factors, farmers have always faced quite significant risks in their overall operations. Meuwissen et al. (2001) studied 612 Dutch livestock farmers to identify the specific risks they faced; these included financial performance, human resources, pricing, production, regulatory demands, and technological changes. Although the availability of formal insurance plans may induce poor and rural households to make productive investments (Farrin and Mirinda, 2015) to mitigate risk factors, they might not make the investment if they have access to other informal risk management mechanisms. Poor and rural households may opt for formal insurance plans if those plans are linked to other forms of financial support. Alternatively, some poor farmers forego insurance plans yet mitigate risk by adopting technology to better manage their farms. In agrarian communities, consumption credit may serve as an insurance contract tool, thereby affecting risk behavior and decisions about what farmers can produce (Eswaran and Kotwal, 1989). One of the risk pooling practices in agrarian areas is the provision of loans that are distributed among relatives or small community farmers, as seen in Nigeria (Udry, 1990). Here, the repayment arrangement is contingent upon production and consumption shocks are shared by both parties (the borrower and the lender). 
Over-valuation of assets by farmers is a real problem for insurance firms, especially if a firm is remotely located. Geographic distances may make it difficult for insurers to accurately verify the insured assets against loss probabilities, allowing high risk individuals to raise their insurance coverage. The financial viability of the insured, and other fraudulent activities prevailing in the insurance business, are moral hazards for insurance providers (Dalal and Morduch, 2010). The insurance business assumes the moral hazard, whereas the insured can gain a lot in claims payment, with little to lose when they lie or give inaccurate assessment, which may then destabilize the insurance system.

Low-income people buy insurance if the products meet their needs and are fairly priced. If insurance products are designed too generally and do not adequately meet consumer needs and consumer expectations, they usually fail. Insurance products offering better quality, a wide range of prices and coverage levels, and faster claim settlement procedures are more likely to convince consumers to buy insurance.

To overcome income variability, insurance service suppliers should offer premium payment plans that ensure an efficient collection system. Many clients are skeptical about paying premiums for an elusive product that in their view has benefits that may never be claimed. In addition, they often mistrust insurance firms (Njuguna and Arunga, 2013). Meuwissen et al. (2001) discussed relative risk attitude and Flaten et al. (2005) studied comparative risk aversion. They found that a farmers' attitude towards risk basically reflects a farmer's willingness to take on risk. These research scholars emphasized that farmers are typically more willing to take on risk than those in other economic sectors. Explaining farmers' willingness to take on risk is an attempt to explain a sort of economic behavior.

\subsection{Farmers Individual Characteristics}

Age: Many researchers cite age as an important variable in risk-taking behavior. Mischra and Goodwin (2005) suggested that younger people are more adventurous and therefore less risk averse than older people. However, Aye and Oji (2006) suggested that older farmers are more willing to take on risk. These opposing findings may be due to differing cultural perceptions about the concept of risk and how to react to it.

Farm characteristics (type and size): Attitudes vary, depending on the type of livestock a farmer raises - dairy cattle, buffalo, pigs, poultry, goat, or bull. Since different kinds of farmers face dissimilar circumstances, they may have different attitudes towards risk and how to deal with it. For example, dairy farmers have received plenty of support from governments and other organizations for many years. This is in contrast to pig and poultry farmers, who produce for the global free market without any kind of government or organizational support. However, in coming years, support for the dairy sector will be reduced and today the dairy sector faces enormous uncertainty about how to develop the dairy market. It can therefore be suggested that support levels have an influence on a farmer's risk attitude (Mahul and Stutley 2010). In addition, Jing et al., (2001) hinted that persons with a higher number of businesses, higher gross sales, and higher numbers of employees are often wealthier and willing to take on more risk. Also, larger farms have better future potentials and are therefore more likely to take on risk.

\subsection{Role of Insurance Companies in Technological Adoption}

Poor and rural households are likely to subscribe to insurance if it is available to grow their business. This is true when they have access to informal risk-coping mechanisms (Farrin and Miranda, 2015). This is especially the case when insurance is paired with access to other types of financing.

When the household demand for technology and finance in terms of credit and insurance are dissected with regard to three scenarios: (i) no insurance; (ii) stand-alone index insurance; and (iii) interlinked credit-index insurance contracts, a different setup comes into play (Carter, Cheng and Sarris, 2011). Researchers found that the three scenarios mentioned above affect demand at different levels according to the amount of collateral held by the household. Insurance-only plans can significantly increase demand for both technology and financial products among high-collateral households. On the other hand, businesses with low levels of collateral actually exhibit lower demand for technology, when compared to the baseline of no insurance, when insurance-only contracts are in place. Moreover, interlinked contracts escalate demand for technology among both low- and high-collateral households.

Faced with highly variable climate conditions, farmers seek types of livestock less sensitive to fluctuating weather conditions. However, this reaction is mitigated if farmers are higher-income, with higher levels of capital. Surveyed farmers who in the bottom 80th percentile in wealth exhibited higher variability in profit. In contrast, the top $20 \%$ percentile of farmers in wealth were able to withstand profit risk due to a decrease in rainfall (Rosenzweig and Binswanger, 1993; Farrin, 2013). 
Technology adoption factors have an insurance utility even when there are no formal markets for risk reduction mechanisms or management. Consumption credit availability to agrarian communities can serve as an insurance contract and therefore, influence risk behavior and production decisions (e.g., technological innovation and investment levels) of farmers (Eswaran and Kotwal, 1989).

Potential insurance clients face a range of risks, however not all of these risks can be feasibly insured (Roth et al., 2007). Hence, the insurance products designed and offered may fail to meet consumer expectations (Brown and McCord, 2000). Clients usually do not intelligently distinguish between the myriad policies offered by competing insurance companies (Association of Kenya Insurers, 2008). Product features affect the quality of each policy. While insurance clients prefer high quality products, which provide faster claim settlement, fewer exclusions and wider coverage, they may not be able to buy such higher priced insurance products. Prahalad (2005) argued that low-income people are brand conscious and would prefer high quality insurance services.

\subsection{Insurance Pricing}

Insurance pricing is a challenge because insurers need to balance prices, costs, sustainability, and affordability. Premiums should encompass all claims and operating expenses, as well as generate profit. People's need for insurance depends on their income level and personal preference (Brown and McCord, 2000). Without economies of scale, the insurance policy is considered unrewarding, as consumers often must pay an administrative cost that is even more than the insurance policy premium. The premium often includes operating expenses, which include distribution, underwriting, claims assessment, and transaction costs for administration and premium collection (Lybbert et al., 2004). In general, data deficiency presents a constraint in measuring a pricing method's effectiveness. To overcome this issue, insurers may factor in an error margin, which must be adjusted once claims are lodged. Churchill (2007) suggested using actuarial services as a pricing adjustment for micro-insurers.

Moral hazards can be minimized by scrutinizing claims. Claims scrutiny criteria must be taken into account when insurers design their policies. One way insurers can reduce moral hazard incidents is to build and establish a network of relationships within each community, thereby making clients more sensitive to the need to only make genuine claims (Dalal and Morduch, 2010). Insurance applicant screening also helps to minimize adverse selection by denying insurance coverage to clients deemed risky. Insurance providers need to develop and implement premium payment structures that ensure better collection. At the same time, payments can be scheduled to coincide with those times during the year when policyholders receive income, such as harvest time or when they collect grants or government cash transfers (Siegel et al., 2001).

\subsection{Public Awareness}

Many clients are not convinced that they should pay insurance premiums for an intangible product with benefits not yet consumed or claimed. Also, they often harbor a basic distrust of insurance companies. Some insurers distribute information to educate low-income households on the need for risk reduction and management in their businesses, explaining micro-insurance and other options. Policies targeting micro and small businesses need to be differentiated from conventional insurance products (Siegel et al. 2001).

In areas where levels of insurance literacy are low, campaigns to disseminate such useful information are required. It is essential that micro-insurance companies settle claims and recover losses quickly - at a minimum - to prevent customers from losing faith and interest in their insurance policies. To make micro-insurance plans successful and attractive, insurance companies must satisfy their clients through comprehensive programs and understandable language and procedures (Fischer and Qureshi, 2006).

\subsection{Risk Management}

Micro-insurance clients require that service providers develop a simple yet rigorous micro-insurance policy framework that is easy to comprehend. These firms should carry documentation of existing risk management arrangements and micro-insurance practices. At the same time, insurance companies should provide data on predominant risk, classified by farm areas and client demographics (Makove, 2011).

Low income and micro farmers have unique requirements that can be addressed through development of risk measurement models. The models can then be used during underwriting, with a focus on customer needs, product design, delivery systems, and even business models (Njuguna and Arunga, 2013).

\section{Research Methodology}

For the purpose of this research, both qualitative and quantitative methodologies have been used. Quantitative information collected from insurance companies offering insurance for livestock farmers was analyzed. Interviews 
with both commercial livestock farmers (small and large) and insurance agents were conducted in order to evaluate the identical risk factors. Data was collected from 50 commercial farmers from District Hyderabad Sindh of Pakistan. Also, included in the sample are 50 insurance agents of three insurance companies working in Sindh; namely, Adamjee Insurance Company Limited, Jubilee General Insurance Company Limited, and United Insurance Company. The total number of respondents numbered 100 . The instrument used for this study was a self-designed questionnaire to collect data. Because this instrument had not been tested elsewhere the answers to the open-ended questions were varied. Secondary data was collected by questionnaire from insurance companies offering livestock insurance. Primary data was collected from livestock farmers through a custom-designed questionnaire. The responses to survey questions about risk were measured on a five point Likert scale, ranging from (1) strongly agree to (5) strongly disagree. To analyze risks, simple percentage and logistic regression were used to identify the most influential risk management factors for insurance companies. The regression model developed includes one dependent variable (risk assessment) and five independent variables (limited distribution, moral hazard, public awareness, insurance products, and client's risk).

\section{Results}

\subsection{Insurance Products Offered by Companies}

Insurance company product names and purposes are provided in Table 1. The insurance companies are located in the Sindh region of Pakistan. The analysis of product offerings and purposes was done by simple percentage.

Table 1. Insurance products offered by the companies

\begin{tabular}{lll}
\hline $\begin{array}{c}\text { Insurance Company } \\
\text { Name }\end{array}$ & \multicolumn{1}{c}{ Product } & \multicolumn{1}{c}{ Purpose } \\
\hline Adamjee Insurance Co. & $\begin{array}{l}\text { Death coverage of animal from } \\
\text { natural causes, disease, injury, or } \\
\text { accident }\end{array}$ & $\begin{array}{l}\text { Protection of livestock and to secure } \\
\text { necessities related to livestock }\end{array}$ \\
\hline Jubilee Insurance Co. & $\begin{array}{l}\text { Death coverage in case of property } \\
\text { (fire); marine (flood); or drought }\end{array}$ & $\begin{array}{l}\text { Secure necessities related to livestock } \\
\text { dependent on specific needs of } \\
\text { livestock }\end{array}$ \\
\cline { 2 - 3 } & Covers against livestock losses \\
\hline United Insurance Co. & $\begin{array}{l}\text { Livestock loans } \\
\text { Animals death, theft , and risk in } \\
\text { calving }\end{array}$ & $\begin{array}{l}\text { To underwrite the insurance business } \\
\text { products }\end{array}$ \\
\hline
\end{tabular}

\subsection{Characteristics of Insurance Agent Respondents}

The characteristics of insurance agent respondents are presented in Table 2. The data describes the respondents' job experience, the number of years the insurance policies were offered by each company and the departments in which the respondent worked. Fifty-eight percent of the respondents have worked for less than two years in the business. The majority are in the claims department (36\%) and underwriting (30\%). Over half of the companies have offered insurance services for less than two years.

\subsection{Field Experience of Livestock Farmers}

Success in any kind of business, job, or work depends upon the skills and experience of the person or the stakeholder; longer personal experience usually leads to better management and increased profit. Table 3 shows the length of experience among livestock farmers. Out of the 50 farmers, $14 \%$ had 1-10 years of experience, and the majority had between 31-40 years of experience (40\%).

\subsection{Description of Herd Size of the Farm}

Herd size and animal type are directly correlated with livestock owners' profits. Table 4 depicts the herd size and kind of animals kept at the farm. It shows that a herd size of 1-100 animals consists of $24 \%$ cattle and $76 \%$ buffalo. A herd size of 101-200 animals has $42 \%$ cattle and 58\% buffalo. A herd size of 201-300 animals has 55\% cattle and $45 \%$ buffalo. Farms with more than 300 animals hold $30 \%$ cattle and $70 \%$ buffalo. 
Table 2. Characteristics of insurance agent respondents

\begin{tabular}{|c|c|c|c|}
\hline Particulars & Length (in years) & $\mathbf{N}$ & Percent \\
\hline \multirow{4}{*}{ Job experience } & Less than 2 years & 29 & $58 \%$ \\
\hline & $3-4$ years & 9 & $18 \%$ \\
\hline & $5-6$ years & 6 & $12 \%$ \\
\hline & More than 6 years & 6 & $12 \%$ \\
\hline & Total & 50 & $100 \%$ \\
\hline \multirow{4}{*}{$\begin{array}{l}\text { Companies offer } \\
\text { insurance }\end{array}$} & Less than 2 years & 30 & $60 \%$ \\
\hline & $3-4$ years & - & - \\
\hline & $5-6$ years & - & - \\
\hline & More than 6 years & 20 & $40 \%$ \\
\hline & Total & 50 & $100 \%$ \\
\hline \multirow{5}{*}{ Departments } & Underwriting & 15 & $30 \%$ \\
\hline & Risk management & 9 & $18 \%$ \\
\hline & Claims & 18 & $36 \%$ \\
\hline & Marketing, Product design, Strategy & 8 & $16 \%$ \\
\hline & Total & 50 & $100 \%$ \\
\hline
\end{tabular}

Table 3. Personal field experience of livestock farmers

\begin{tabular}{lcc}
\hline Valid & Frequency & Percent \\
\hline $1-10$ years & 7 & $14 \%$ \\
\hline $11-20$ years & 9 & $18 \%$ \\
\hline $21-30$ years & 10 & $20 \%$ \\
\hline $31-40$ years & 20 & $40 \%$ \\
\hline Above 40 years & 4 & $8 \%$ \\
\hline Total & 50 & $100 \%$ \\
\hline
\end{tabular}

Table 4. Description of farm herd size

\begin{tabular}{lcc}
\hline Number of Animals at the Farm & Cattle & Buffalo \\
\hline $1-100$ & $24 \%$ & $76 \%$ \\
\hline $101-200$ & $42 \%$ & $58 \%$ \\
\hline $201-300$ & $55 \%$ & $45 \%$ \\
\hline Above 300 & $30 \%$ & $70 \%$ \\
\hline
\end{tabular}

\subsection{Insurance Policy Information}

Ninety percent of the farmers surveyed said they had never purchased any kind of livestock insurance. Only $10 \%$ of farmers had knowledge of livestock insurance and had purchased it, as shown in Table 5. 
Table 5. Insurance policy purchased

\begin{tabular}{lcc}
\hline Valid & Frequency & Percent \\
\hline No & 45 & $90 \%$ \\
\hline Yes & 5 & $10 \%$ \\
\hline Total & 50 & $100 \%$ \\
\hline
\end{tabular}

\subsection{Sources of Risks}

The sources of risk and difficulty faced by livestock farmers are assessed as shown in Table 6. The key data is related to cross-cutting issues for farmers. The table identifies limiting factors and sources of risk faced by livestock farmers. The most important risks faced by livestock farmers in this study were animal health and diseases, such as outbreaks of bacterial and viral disease $(90 \%)$, the high cost of input prices $(84 \%)$, drainage problems in dairy farm areas $(80 \%)$, and shortage of skilled labor $(74 \%)$.

Table 6. Sources of risks

\begin{tabular}{lcc}
\hline \multicolumn{1}{c}{ Valid } & Frequency & Percent \\
\hline Animal health / diseases & 45 & $90 \%$ \\
\hline High input price & 42 & $84 \%$ \\
\hline Drainage problem & 40 & $80 \%$ \\
\hline Labor / manpower & 37 & $74 \%$ \\
\hline Machinery problem & 35 & $70 \%$ \\
\hline Low conception rate & 28 & $65 \%$ \\
\hline Unused resources & 32 & $62 \%$ \\
\hline Fodder problem & 29 & $58 \%$ \\
\hline Lack of equipment & 25 & $50 \%$ \\
\hline Low productivity & 27 & $45 \%$ \\
\hline
\end{tabular}

\subsection{Perceptions of Farmers}

Regarding farmers' perceptions of insurance products, Table 7 reveals that the high cost of insurance is the most important hindrance to buying it (24\%). In addition, farmers assert that they are unaware of any livestock insurance policies that offer protection in case of an emergency (20\%).

Other factors related to low insurance enrollment include: insurance agents' failure to approach farmers to explain the policies (18\%) and respondents being unaware that the needed policy is offered $(16 \%)$.

Table 7. Perceptions of farmers

\begin{tabular}{lcc}
\hline \multicolumn{1}{c}{ Valid } & Frequency & Percent \\
\hline Insurance programs unaffordable & 12 & $24 \%$ \\
\hline Unaware of the importance of livestock insurance & 10 & $20 \%$ \\
\hline Not approached by insurance agents & 9 & $18 \%$ \\
\hline Unaware the policy is offered & 8 & $16 \%$ \\
\hline Willing to participate in full schemes & 4 & $8 \%$ \\
\hline Insurance policies are not attractive & 4 & $8 \%$ \\
\hline Assets are complex & 3 & $6 \%$ \\
\hline
\end{tabular}




\subsection{Risks Faced by the Insurance Service Providers}

The objective of regression analysis is to use different independent variables to anticipate the single dependent variable and in order to test whether or not correlations exist between the dependent and independent variables. In this case, the dependent variables are non-metric. The logistic regression technique is suitable for analysis when the dependent variable is non-metric and has several independent variables, resembling an S-shaped curve.

This base model can provide a standard for comparison where a stepwise regression is conducted. The entry selection of independent variable into the model can be based on the greatest reduction in the -2LL value; the greatest Wald coefficient (Abro et al., 2009). In this study, the greatest value of Wald coefficient is employed as the criteria for selecting the independent variable.

\subsection{Regression Model}

The regression model links the dependent variable (risk assessment) to the independent variables (limited distribution, moral hazard, public awareness, insurance products, and client risk). To assess model fit, several key measures should be considered. First is the change of -2LL value. It could be seen that in the single model, the -2LL value is reduced significantly; from the base model value of 132.367 to 128.976 , indicating a decrease of 127.344. In the two and three-variable model, the -2LL values are also reduced significantly; from 128.976 in the single model to 125.132 in the three-variable model. In the four-variable model, -2LL value decreased from 125.132 in the three-variable model to 119.780. In the five-variable model, -2LL value decreased from 119.780 in the four-variable model to 112.738 . It is suggested that the smaller the -2LL values, the better the model fit.

The next measures are the values of the Cox and Snell R2. The higher value through each stage of the stepwise process indicates the higher the level of model fit. In this case, the Cox and Sell $\mathrm{R}^{2}$ and Nagelkerke $\mathrm{R}^{2}$ values increase gradually from .412 and .567 in the first single model to .572 and .755 in the fifth-variable model.

The third measure considered is the change of the R2 value, based on the change of -2LL values from the initial model to the full model; the higher the value of R2, the better the model works. In this model, the R2 values have increased through the stepwise logistic regression process; .215 in the single model; .335 in the two-variable model; .390 in the three-variable model; .401 in the four-variable model, and .564 in the five-variable model.

At the last stage of the stepwise logistic regression model, the $\mathrm{R} 2$ value is .564, or converting into percentage, it can be said that 56.4 percent of the variance of the dependent variable is accounted for by the logistic regression equation. This value is strong enough to consider it significant.

The fifth measure that should be considered in assessing model fit is the Hosmer and Lemeshow value, which measures the correspondence of the actual and predicted values of the dependent variable.

There are significant relationships between risk assessment and such predictors as limited distribution, moral hazard, public awareness, insurance products, and client risks. (See Table 8)

Table 8 Wald values of the risks

\begin{tabular}{lc}
\hline \multicolumn{1}{c}{ Variables } & Wald Test \\
\hline Limited distribution & 4.40 \\
\hline Moral hazards & 4.37 \\
\hline Public awareness & 4.33 \\
\hline Insurance products & 4.23 \\
\hline Client risk & 4.18 \\
\hline Adverse selection & 3.88 \\
\hline Aggravated losses & 3.85 \\
\hline Underwriting risk & 3.84 \\
\hline Low penetration & 3.81 \\
\hline Flexible premium & 3.80 \\
\hline
\end{tabular}


When the first two variables (limited distribution and moral hazard) are entered into the model there is an $88 \%$ probability of risks for insurance. When entering all five variables into the model, there is a $90 \%$ probability of risk (Table 9). Therefore, it can be concluded that two variables, limited distribution and moral hazard, have high impact on the probability of risk. Public awareness, insurance products, and client risks also contribute to risk for insurance companies.

Table 9. The Regression model

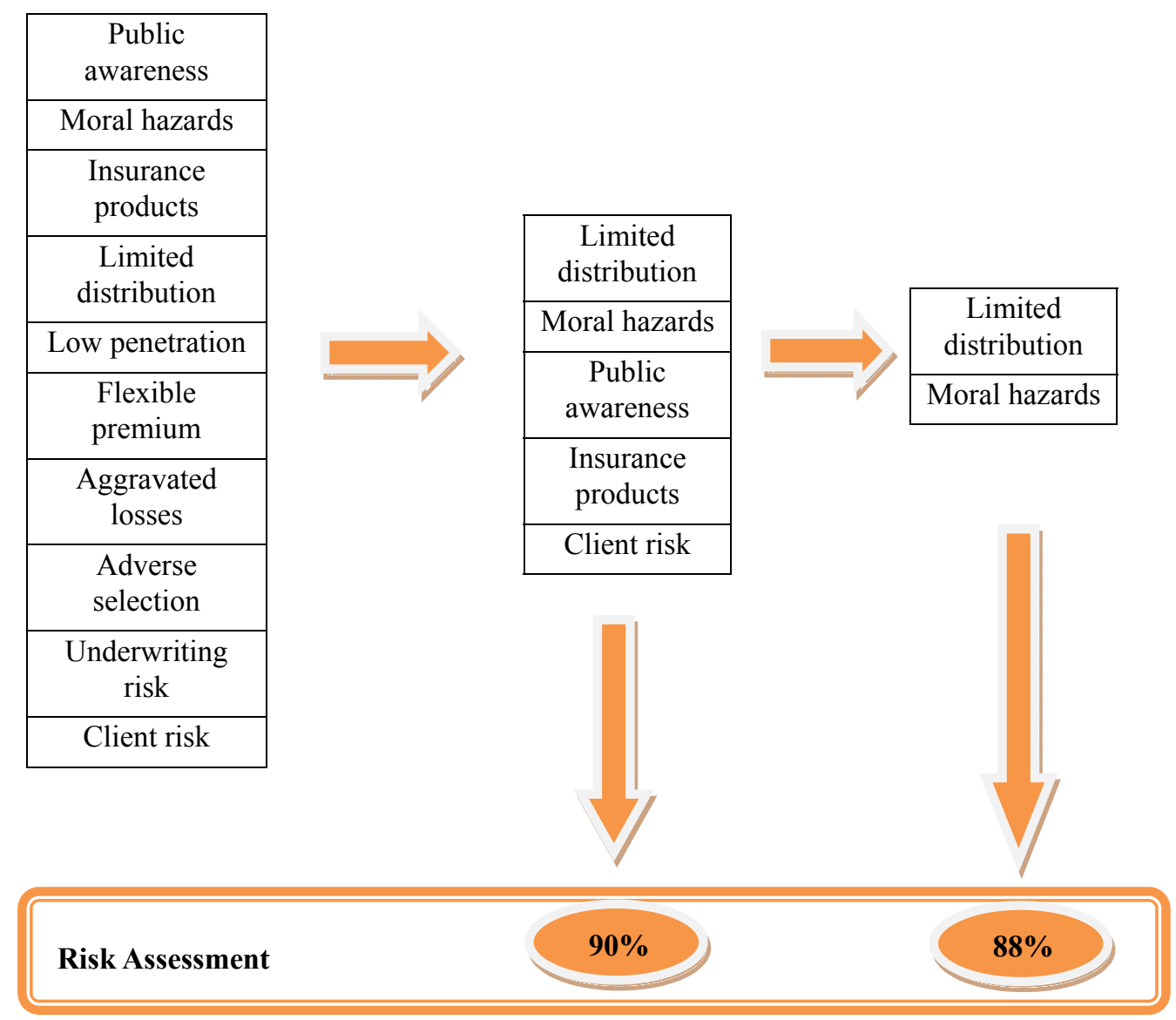

\section{Conclusions and Recommendations}

This study uncovers many findings. To succeed, insurance watchdog agencies should closely monitor the numerous risks facing insurance service providers that inhibit or thwart them from serving the low-end consumer market segment. These risks comprise the absence or dearth of demand for insurance policies (low penetration), limited distribution outlets and branches, and regulations that hinder the expansion of distribution networks and capitalization.

Moreover, for insurance firms to prosper, they should consider using efficient technologies to lower operating expenses, collaborate with other firms in the value chain, regularly assess price movements, and employ actuarial analyses of current and future risks inherent in insurance policies and instruments. In addition, insurance service providers should explore avenues for farmers to receive government and other benefactors' support and subsidies to make insurance policies available at a reasonable premium.

Lastly, the study recommends that insurance sector regulators should reconsider capital requirements and distribution channel setups and branches, and evaluate existing laws and practices to monitor and support insurance firms so they can better and more efficiently serve the needs of small livestock farmers.

\section{Acknowledgment}

The researchers would like to thank the Deanship of Scientific Research at King Saud University represented by the Research Centre in the College of Business Administration for financially supporting this research. 


\section{References}

Abro, Q. M., Memon, N. A., \& Rashdi, P. I. S. (2009). Strategic factors for enhancing the innovativeness of the nanotechnology firms. International Journal of Business Innovation and Research, 3(6), 582-598.

Association of Kenya Insurers (AKI). (2008). Understanding the Uninsured Market. Final Report by SBO Research, February, 3-9.

Aye, G. C., \& Oji, K. O. (2006). Effect of Poverty on Risk Attitudes of Farmers in Benue State, Nigeria. Department of Agricultural Economics, University of Nigeria, Nsukka.

Brown, W., \& McCord, M. J. (2000). Microenterprise Best Practices (MBP) Project. Virtual Conference on Micro insurance, USAID, Development Alternatives / USAID.

Carter, M. R., Cheng, L., \& Sarris, A. (2011). The Impact of Interlinked Insurance and Credit on Financial Market Deepening and Small Farm Productivity. UC Davis. Mimeo.

Churchill, C. (2007). Insuring the Low-Income Market: Challenges and Solutions for Commercial Insurers. Geneva Papers on Risk and Insurance, 32, 401-412.

Dalal, A., \& Morduch, J. (2010). The Psychology of Microinsurance: Small Changes Can Make a Surprising Difference. Micro-insurance Paper No. 5. Geneva: International Labor Organization.

Eswaran, M., \& Kotwal, K. (1989). Credit as Insurance in Agrarian Economies. Journal of Development Economics, $31(1), 37-53$.

Farrin, K. (2013). Escape from Poverty Traps: Three Essays on the Effects of Policy Intervention on Agricultural Productivity and Welfare among the Rural Poor. Doctoral Dissertation, Ohio State University.

Farrin, K., \& Miranda, M. (2015). A Heterogeneous Agent Model of Credit-Linked Index Insurance and Farm Technology Adoption. Journal of Development Economics, 116, 199-211.

Fischer, K., \& Qureshi, Z. (2006). Cooperatives and Insurance: The Mutual Advantage in Protecting the Poor: A Micro-Insurance Compendium. Geneva: International Labor Organization and Munich Re-Foundation Publication.

Flaten, O., et al. (2005). Comparing Risk Attitudes and Risk Management in Organic and Conventional Dairy Farming: Empirical Results from Norway. Elsevier Livestock Production Science, 95, 11-25.

Jing, J. X., et al. (2001). Attitude toward Risk and Risk-Taking Behavior of Business-Owning Families. Journal of Consumer Affairs, 35(2), 307-325.

Lybbert, T. J., Barrett, C. B., Desta, S., \& Coppock, D. L. (2004). Stochastic Wealth Dynamics and Risk Management Among a Poor Population. The Economic Journal, 114(4), 750-777.

Mahul, O., \& Stutley, C. J. (2010). Government Support to Agricultural Insurance. Washington, DC: The World Bank

Makove, S. M. (2011). African Policy Approaches: Microinsurance in Kenya. AIO - A2ii Regulators' Workshop. Victoria Falls, Zimbabwe.

Meuwissen, M. P. M. et al. (2001). Risk and Risk Management: an Empirical Analysis of Dutch Livestock Farmers. Elsevier Livestock Production Science, 69, 43-53.

Mischra, A. K., \& Goodwin, B. K. (2005). Revenue Insurance Purchase Decisions of Farmers. Journal of Applied Economics, 38, 149-159.

Njuguna, A. G., \& Arunga, A. (2013). Risk Management Practices: A Survey of Micro-Insurance Service Providers in Kenya. International Journal of Financial Research, 4(1), 132-150.

Prahalad, C. K. (2005). Fortune at the Bottom of the Pyramid: Eradicating Poverty through Profits. Wharton School Publishing.

Rosenzweig, M. R., \& Binswanger, H. B. (1993). Wealth, Weather Risk and the Composition and Profitability of Agricultural Investments. The Economic Journal, 103, 56-73.

Roth, J., McCord, M. J., \& Liber, D. (2007). The Landscape of Microinsurance in the World's 100 Poorest Countries. Appleton, WI: The MicroInsurance Centre, LLC.

Siegel, P., Alwang, B. J., \& Canagarajah, S. (2001). Viewing Micro-insurance as a Social Risk Management Instrument. Discussion Paper Series, No. 116. Washington, DC: World Bank.

Udry, C. (1990). Credit Markets in Northern Nigeria: Credit as Insurance in a Rural Economy. World Bank Economic Review, 4(3), 251-269. 